\title{
Prevalence of 3.7 and 4.2 Deletions in Sudanese Patients with Red Cells Hypochromia and Microcytosis
}

\author{
Hussam Ali Osman ( $\nabla$ hussomco@gmail.com ) \\ Ahfad University for Women https://orcid.org/0000-0002-2017-2331 \\ Muzamil Mahdi Abdel Hamid \\ University of Khartoum \\ Rahimah Binti Ahmad \\ Institute for Medical Research, Jalan Pahang 50588 Kuala Lumpur, Malysia \\ Mohamed Saleem \\ Advanced Genomics SDN BHD (GenomixLAB), kota damansara, Malaysia \\ Sana Altahir Abdallah \\ Alneelain University
}

Research note

Keywords: Alpha Thalassemia, PCR, Homozygous, Heterozygous, Deletion mutations, Multiplex GAP

Posted Date: January 9th, 2020

DOI: https://doi.org/10.21203/rs.2.20530/v1

License: @) (7) This work is licensed under a Creative Commons Attribution 4.0 International License. Read Full License

Version of Record: A version of this preprint was published at BMC Research Notes on February 10th, 2020. See the published version at https://doi.org/10.1186/s13104-020-4933-5. 


\section{Abstract}

Objective: Alpha-thalassemia is a genetic disorder characterized by deletions of one or more a globin genes that result in deficient of a globin chains reducing haemoglobin concentration. The study aimed to screen 97 patients with microcytosis and hypochromasia for the 3.7 and 4.2 alpha thalassemia deletion mutations.

Results: Out of 97 patients screened, only 7 were carriers for the 3.7 deletion and all patients were negative for the 4.2 deletion. The 3.7 deletion was found in Foor, Hawsa and Rezagat Sudanese tribes. In the carriers of the 3.7 deletion, Red Blood Cells and Haematocrit were significantly increased. The Red Blood Cells were $7.23 \pm 0.78 \times 1012 / \mathrm{L}$ in adult males and $7.21 \pm 0.67 \times 1012 / \mathrm{L}$ in adult females while in children were $5.07 \pm 0.87 \times 1012 / \mathrm{L}$. The mean cell volume and mean cell haemoglobin were significantly decreased, but the mean cell haemoglobin concentration slightly decreased. Haemoglobin levels didn't revealed statistically significant decrease in adult males $(11.7 \pm 0.57 \mathrm{~g} / \mathrm{dL})$ and adult females $(11.25 \pm 0.64 \mathrm{~g} / \mathrm{dL})$, while in children were $(11.6 \pm 2.95 \mathrm{~g} / \mathrm{dl})$. Haemoglobin electrophoresis revealed two patients of the 3.7 and 4.2 negative were carriers for b-thalassemia. The study concluded that a 3.7 deletion has frequency of 0.07 in Sudanese with hypochromasia and microcytosis.

\section{Introduction:}

Thalassemia is a hereditary blood disorder in which there is impaired synthesis of one or more globin chains of haemoglobin. ${ }^{(1 \& 2)}$ It was discovered for the first time by Cooley and Lee in 1925. (3) Thalassemia syndromes can be conveniently classified according to the type of globin chain affected. Of these, there are two which are of special importance; they are called $\alpha$-thalassemia and $\beta$-thalassemia. Others such as $\delta \beta, \gamma \delta \beta, \delta, \gamma$ and $\varepsilon \gamma \delta \beta$ thalassemia are rare. Unlike $\beta$-thalassemia, the most common molecular defects in alpha thalassemia is due to large deletions involving either or both HBA1 and HBA2 genes. Most

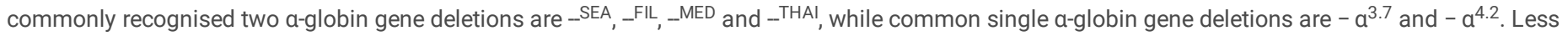
frequently, a-thalassemia results from single-nucleotide variants. Historically, the distribution of a-thalassemia follows a pattern consistent with the degree of malaria endemicity and shows a highest prevalence in Africa with an allele frequency of $0.3-0.4$ for $-a^{3.7}$ deletion. Alpha thalassemia is also common in

Southeast Asian countries like Thailand, Laos, and Vietnam. ${ }^{(4,5)}$ The a-thalassemia has a wide range of distribution globally, so annually 300,000 thalassemia patients are born. It affects $5-40 \%$ of the population in Africa and $40-80 \%$ in South Asia. ${ }^{(4,6)}$ The prevalence and frequency of the disease into an increase globally because of the migration worldwide. ${ }^{(7)}$

Although the incidence and prevalence of alpha thalassemia is known to be increased in the African countries, its exact incidence or prevalence in Sudanese remains unknown, so we hypothesized there are many asymptomatic carriers for alpha thalassemia mutations masked in Sudanese community.

\section{Methods:}

This is a cross sectional study, aimed to determine most common types of alpha thalassemia mutations in Africans ( 3.7 and 4.2 deletion mutations) on molecular basis and to correlate the finding with haematological parameters. Blood samples were analyzed at the Biotechnology Research Laboratory, Ahfad University and the department of Molecular Biology, Institute of Endemic Diseases, University of Khartoum. A total number of 97 patients with age ranged between 12-63 years old attended the clinical laboratories of six hospitals in Khartoum City (Khartoum Teaching Hospital, Omdurman Maternity Hospital, Gafer Ibn Oaf Paediatric Hospital, Mohamed Elamin Hamid Paediatric Hospital, Omdurman Teaching Hospital and Albuluk Paediatric Hospital) for routine check-up, were randomly selected on bases of the microcytosis ( $\mathrm{MCV}<80 \mathrm{fL}$ in adults or $<75 \mathrm{fL}$ in children), hypochromasia (MCH $<27 \mathrm{pg}$ ), normal ferritin level to exclude iron deficiency anaemia, no history and currently free of malaria infection and chronic disorders. Data were collected by observation of laboratory investigations and a well-designed questionnaire used for data collection. Complete blood counting was done using an automatic multi-parameter Haematology Analyzer (Sysmex kx-21) for in vitro diagnostic in the clinical laboratories in-order to detect the abnormalities. Alkaline haemoglobin electrophoresis method was carried out to detect the coinheritance of hemoglobinopathy mainly the sickle cell anaemia, heterozygous B-thalassemia, $\mathrm{Hb} \mathrm{H}$ or $\mathrm{Hb}$ Barts, using SAS-MX Alkaline Hb-10 kit (Helena Bioscience Europe), then the types and percent of Hb were measured by densitometry method. Ferritin level was measured using full automated Cobas e411 (Roche, German). ${ }^{(8)}$ The genomic DNA was extracted using genomic DNA purification kit for whole blood (Jena Bioscience, Germany). The quantity and quality of extracted DNA was measured by a Nanodrope Spectrophotometer ND1000. Single tube multiplex Gap-PCR was done to screen all the 97 patients for the presence of the $-a^{3.7}$ and $-a^{4.2}$ deletions using the Platinum Multiplex PCR Master Mix (Invitrogen Applied Biosystem USA). The set of the primers used were supplied by Invitrogen Applied Biosystem, Germany). The sequence of the primers used were according to Chong, S. S. ${ }^{(9)}$ A large (2.5 kilo base) region of the LIS1 gene (Lissencephaly 1gene) was co-amplified as an internal PCR control. Positive control genomic DNA samples were kindly provided by the Medical Research Institute- Kuala Lumpur, Malaysia. All data were analysed by SPSS version 14 and the p. values were calculated by paired sample t test.

\section{Multiplex GAP-PCR:}

Before starting all reagents were allowed to thaw at room temperature, gently mixed by tube inverting and spin down. The reaction mixes were prepared according to the Platinum Multiplex PCR Master Mix manufacturer guidelines, ${ }^{(10)}$ so each 25 uL reaction mix contained 12.5 uL Platinum Multiplex PCR Master Mix (2X), 5 uL GC enhancer (2X), 3.25 uL Primer Mix, 1 uL DNA (100 ng/uL) and 3.25 uL of Nuclease-free water. Senso Quest labcycler 48 (Germany) was used for PCR amplification with the initial denaturation at $95^{\circ} \mathrm{C}$ for $5 \mathrm{~min}$, followed by followed by 30 cycles of denaturation at $97{ }^{\circ} \mathrm{C}$ for 45 sec, annealing at $60{ }^{\circ} \mathrm{C}$ for $1 \mathrm{~min} 15$ seconds and $72{ }^{\circ} \mathrm{C}$ for $2 \mathrm{~min} 30$ seconds, with a final extension at $72{ }^{\circ} \mathrm{C}$ for 5 min. PCR amplicons were analysed by electrophoresis on $1 \%$ agarose gel dissolved in $1 \times$ Tris-Borate-EDTA buffer at 90 volts (current 40 amperes) for 2 hours. The gels were stained and visualised under UV light. 


\section{Results:}

A total number of 97 patients were enrolled in the study, 67 of them were children (12-17 years old) including ( 30 males and 37 females) and 30 adults (1863 years old) including (12 males and 18 females). All patients were Sudanese distributed in 36 Sudanese Tribes. On basis of the molecular biology investigations, 7 out of 97 individuals presented heterozygous $-a^{3.7}$ deletion, while none was positive for $-a^{4.2}$ deletion (Fig. 1): Multiplex PCR products on agarose gel electrophoresis) and these 7 carriers were belong to tribes of Foor, Hawsa and Rezagat that originated from West Africa.

The means of RBCs count for carriers were significantly increased in adults males and females $\left(7.23 \pm 0.78 \times 10^{12} / \mathrm{L}\right.$ and $7.21 \pm 0.67 \times 10^{12} / \mathrm{L}$, respectively) while were normal $\left(5.06 \pm 0.87 \times 10^{12} / \mathrm{L}\right)$ in children. $\mathrm{Hb}$ level was mildly decreased; which were $11.70 \pm 0.57 \mathrm{~g} / \mathrm{dL}, 11.25 \pm 0.64 \mathrm{~g} / \mathrm{dL}$ and $11.6 \pm 2.95 \mathrm{~g} / \mathrm{dL}$ in males, females and children, respectively. The means of haematocrit (HCT) were $38.70 \pm 3.25 \%, 37.65 \pm 2.33 \%$ and $35.06 \pm 7.38 \%$ in males, females and children, respectively. MCV in adults was clearly decreased; $53.60 \pm 1.27 \mathrm{fL}$, and $52.35 \pm 1.63 \mathrm{fL}$ in males and females, while in children was $69.20 \pm 7.49 \mathrm{fL}$. $\mathrm{MCH}$ was $16.25 \pm 0.92 \mathrm{pg}, 15.60 \pm 0.57 \mathrm{pg}$ and $22.80 \pm 3.44 \mathrm{pg}$ in males, females and children, respectively. MCHC was $30.25 \pm 1.06 \%, 29.90 \pm 0.14 \%$ and $32.86 \pm 1.64 \%$ in males, females and children, respectively. The means RDW_CV were $20.20 \pm 1.70 \%$ and $21.05 \pm 0.07 \%$ in the adults (males and females respectively) and in children were $14.86 \pm 0.95 \%$. The types of haemoglobin in the study population according to the electrophoresis result revealed, 2 beta thalassemia trait patients, have increased $\mathrm{Hb} \mathrm{A}$ ( $\varangle 3.5 \%), 11$ patients have $\mathrm{Hb}$ AS and 77 patients have normal haemoglobin $(\mathrm{Hb} \mathrm{AA})$ and no other haemoglobin variants detected. All carriers have normal haemoglobin ( $\mathrm{Hb} \mathrm{AA})$ and no $\mathrm{Hb} \mathrm{H}$ or $\mathrm{Hb}$ Barts were found.

Table (1): Haematological parameters of the study patients:

\begin{tabular}{|c|c|c|c|}
\hline Parameter & Group & $\begin{array}{l}3.7 \& 4.2-v e \\
(\mathrm{No}=90)\end{array}$ & $\begin{array}{l}3.7 \text { heterozygous } \\
(\mathrm{No}=7)\end{array}$ \\
\hline \multirow{3}{*}{ Number distribution } & Male & 10 & 2 \\
\hline & Female & 15 & 3 \\
\hline & Children & 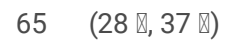 & 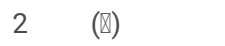 \\
\hline \multirow{3}{*}{$\mathrm{RBC}\left(\mathrm{x} 10^{12} / \mathrm{L}\right)$} & Male & $5.55 \pm 0.77$ & $7.23 \pm 0.78$ \\
\hline & Female & $4.61 \pm 0.39$ & $7.21 \pm 0.67$ \\
\hline & Children & $4.98 \pm 0.74$ & $5.05 \pm 0.87$ \\
\hline \multirow{3}{*}{$\mathrm{Hb}(\mathrm{g} / \mathrm{L})$} & Male & $14.62 \pm 0.87$ & $11.70 \pm 0.57$ \\
\hline & Female & $12.00 \pm 1.70$ & $11.25 \pm 0.64$ \\
\hline & Children & $10.79 \pm 1.50$ & $11.6 \pm 2.95$ \\
\hline \multirow{3}{*}{ PCV (L/L) } & Male & $43.36 \pm 2.06$ & $38.70 \pm 3.25$ \\
\hline & Female & $36.60 \pm 4.56$ & $37.65 \pm 2.33$ \\
\hline & Children & $33.00 \pm 3.75$ & $35.06 \pm 7.38$ \\
\hline \multirow{3}{*}{$\operatorname{MCV}(f L)$} & Male & $67.80 \pm 7.64$ & $53.60 \pm 1.27$ \\
\hline & Female & $69.77 \pm 8.05$ & $52.35 \pm 1.63$ \\
\hline & Children & $67.23 \pm 4.97$ & $69.20 \pm 7.49$ \\
\hline \multirow{3}{*}{$\mathrm{MCH}(\mathrm{pg})$} & Male & $23.44 \pm 2.17$ & $16.25 \pm 0.92$ \\
\hline & Female & $23.18 \pm 2.95$ & $15.60 \pm 0.57$ \\
\hline & Children & $21.99 \pm 2.43$ & $22.80 \pm 3.44$ \\
\hline \multirow{3}{*}{$\mathrm{MCHC}(\%)$} & Male & $34.18 \pm 0.93$ & $30.25 \pm 1.06$ \\
\hline & Female & $32.73 \pm 1.79$ & $29.90 \pm 0.14$ \\
\hline & Children & $32.63 \pm 1.70$ & $32.86 \pm 1.64$ \\
\hline \multirow{3}{*}{ RDW-CV } & Male & $14.26 \pm 1.98$ & $20.20 \pm 1.70$ \\
\hline & Female & $13.75 \pm 1.26$ & $21.05 \pm 0.07$ \\
\hline & Children & $15.77 \pm 2.36$ & $14.86 \pm 0.95$ \\
\hline \multirow[t]{4}{*}{ Frequencies of $\mathrm{Hb}$ electrophoreses result } & AA & 77 & 7 \\
\hline & AS & 11 & 0 \\
\hline & $\mathrm{A}_{2}$ & 2 & 0 \\
\hline & $\mathrm{F}$ & 0 & 0 \\
\hline
\end{tabular}


The above table showed the Haematological parameters and Haemoglobin electrophoresis results in the study population. RBC: Red Blood Cells, Hb: Haemoglobin, PCV: Packet Cell Volume, MCV: Mean Cell Volume, MCH: Mean Cell Haemoglobin, MCHC: Mean Cell Haemoglobin Concentration, RDW-CV: Red Cells Distribution Width Coefficient Variation, AA: Adult Haemoglobin, AS: Haemoglobin AS (carrier Haemoglobin S), A2: Haemoglobin $A_{2}$, F: Foetal Haemoglobin.

\section{Discussion:}

Globally, the frequency of alpha-thalassemia is low, but in some tropical and subtropical areas the frequency of carriers could be high (80-90\%). However, the disease is unexplored in Sudanese, mainly because of the limited accessibility to molecular diagnostic facilities in the country. ${ }^{(11,12,13,14)}$ In this study we report that at least $7 \%$ of hypochromic microcytic anaemia patients were carriers of $-a^{3.7}$ deletion. Since incidence and prevalence of this syndrome was not well described in local populations, it is extremely likely that a-thalassaemia triat may have been confused with iron deficiency state, especially if it was not assessed. ${ }^{(15,16,17,18)}$

The RBCs in adult carriers showed a significant increase in counting with significant association with the mutation "P-value < 0.05 ", while in the children they were normal in count. The increase of RBCs count can be considered as a matter of compensation, a finding that have been reported before. ${ }^{(19,20,21)}$ The haemoglobin concentration revealed mild anaemia in adults and children. This was previously reported ${ }^{(15)}$, where alpha thalassemia trait patients were characterized by slight reduction in haemoglobin level. The MCV and MCH showed microcytosis and hypochromasia in adults, and this finding is consistent with many previous studies concerning the contribution of alpha thalassemia to microcytosis and hypochromia $(21,23,24,25,26,27,28,29)$, while others $(15,22)$ reported slight microcytosis and hypochromasia or sometimes normal with alpha thalassemia trait. The microcytosis and hypochromasia that reported in the current study might be due to a coinheritance of the $\mathrm{a}^{3.7}$ allele with other deletion type or point mutation, such as AC deletion in vicinity of the initiation codon of the $-a^{3.7}$ allele. ${ }^{(30)}$ RDW_CV of the $-a^{3.7}$ heterozygous group revealed anisopoikilocytosis, in adult males and females, while in children showed mild anisopoikilocytosis, this finding is consistent with previous studies. ${ }^{(29,31,32)}$

In conclusion we confirm the presence of $a^{3.7}$ allele in Sudanese with marked microcytosis and hypochromasia, where the disease was unknown before. This suggests that, previous migration from West Africa crossing Sudan was the main cause of transmission of such type of mutation in Sudanese.

Limitations:

The negativity of type 4.2 deletion don't exclude the presence of this type of mutation in Sudanese, so further studies should be done including large number of population from different sites to screen for phenotypes and genotypes types of alpha thalassemia among Sudanese in the future.

\section{List Of Abbreviations}




\begin{tabular}{|c|c|}
\hline CBC & Complete blood count \\
\hline DNA & Deoxyribonucleic acid \\
\hline FIL & Filipino \\
\hline $\mathrm{fl}$ & Femto liter \\
\hline $\mathrm{g} / \mathrm{dL}$ & Gram per dice liter \\
\hline$g / l$ & Gram per liter \\
\hline $\mathrm{Hb}$ & Haemoglobin \\
\hline $\mathrm{Hb} \mathrm{A} 2$ & Hemoglobin $\mathrm{A}_{2}$ \\
\hline $\mathrm{Hb} \mathrm{F}$ & Fetal Haemoglobin \\
\hline $\mathrm{HbCS}$ & Hemoglobin constant spring \\
\hline HCT & Hematocrit \\
\hline EDTA & Ethylenediaminetetra-acetic acid \\
\hline $\mathrm{Kp}$ & Kilo base pare \\
\hline LIS1 & Lissencephaly 1 \\
\hline $\mathrm{MCH}$ & Mean cell haemoglobin \\
\hline $\mathrm{MCHC}$ & Mean cell haemoglobin concentration \\
\hline MCV & Mean cell volume \\
\hline MED & Mediterranean \\
\hline${ }^{\circ} \mathrm{C}$ & Degree centigrade \\
\hline PCR & Polymerase chain reaction \\
\hline $\mathrm{pg}$ & Pico gram \\
\hline RBCs & Red blood cells \\
\hline RDW_CV & Red cell distribution width coefficient variation \\
\hline SEA & Southeast Asia \\
\hline SPSS & Statistical Package for Social Studies \\
\hline STD & Standard deviation \\
\hline THAI & Thailand \\
\hline USA & United State of America \\
\hline ul & Micro liter \\
\hline$-v e$ & Negative \\
\hline WBCs & White blood cells \\
\hline WHO & World health organization \\
\hline a & Alpha \\
\hline$\beta$ & Beta \\
\hline Y & Gamma \\
\hline$\delta$ & Delta \\
\hline$\varepsilon$ & Epsilon \\
\hline$\zeta$ & Zeta \\
\hline
\end{tabular}

\section{Declarations}

\section{Ethics approval and consent to participate}

The ethical approval was obtained from ethical research committee of the faculty of Medicine, Alneelain University and approved by the Federal Ministry of Health in Sudan. Consents were signed by all adult participants' and also the children patients has given parental consent for the study prior to enrolment and used achieved blood samples collected for complete blood counts (CBC) requested by the physician (non-probability sampling). 


\section{Consent for publication}

Not applicable" in this section

\section{Availability of data and material}

All data generated or analyzed in this study are included in this manuscript.

\section{Competing interests}

The authors declare that they have no competing interests" in this section.

\section{Funding}

This work was funded by Ahfad University for Women. The fund covered all expenses of blood sample collection, reagents/chemicals, transportation and the data analysis.

\section{Authors' contributions}

- HAO (principal investigator) and SAE design the experiment framework of the study.

- HAO collected the blood samples and data. HAO and MMA did the laboratory work.

- HAO, MMA, RBA, MS and SAE participate in result analysis and interpretation.

- All authors participated in preparation of the manuscript, revision and coordination.

- All authors read and approved the final manuscript.

\section{Acknowledgement:}

We would like to thank the families and patients for their cooperation and acceptance to participate in the study and we would like also to thank the research team at Institute for Medical Research, Jalan Pahang, Kuala Lumpur, Malaysia for their technical support and providing us with the DNA control samples. Also our deep thanks extend for the medical staff in Khartoum Hospital, Omdurman Maternity Hospital, Gafer Ibn Oaf Pediatric Hospital,Mohamed El AminPediatric Hospital in Omdurman. Omdurman Hospital and AlbulukPediatric Hospital for their cooperation. This work was funded by Ahfad University for Women. The fund covered all expenses of blood sample collection, reagents/chemicals, transportation and the data analysis. We would like to thank Ahfad University for Women for the financial support.

\section{Authors' information}

- Hussam Ali Osman (PhD Haematology), Department of Biotechnology, School of Pharmacy, Ahafad University for Women, Omdurman, Sudan.

- Muzamil Mahdi Abdel Hamid (PhD Molecular Biology), Institute of Endemic Diseases, Medical Campus, University of Khartoum, Sudan.

- Rahimah Binti Ahmad (PhD Haematology) Haematology Unit, Cancer Research Centre Institute for Medical Research Jalan Pahang 50588 Kuala Lumpur, Malaysia.

- Mohamed Saleem (PhD Haematology), Advanced Genomics SDN BHD (GenomixLAB), kota damansara, Malaysia.

- Sana Eltahir Abdalla (PhD Haematology), Department of Pathology, Faculty of Medicine, Alneelain University, Khartoum, Sudan.

\section{References}

1. Kumar V, Abbas AK, Fausto N, Aster JC. Robbins and Cotran pathologic basis of disease, professional edition e-book. Elsevier health sciences; 2014 Aug 27.

2. Rubin R, Strayer DS, Rubin E, editors. Rubin's pathology: clinicopathologic foundations of medicine. Lippincott Williams \& Wilkins; 2008.

3. Cooley TB, Lee P. Series of cases of splenomegaly and peculiar changes in the bones. Trans. Am. Pediat. Soc. 1925;37:29.

4. Porwit A, McCullough J, Erber WN. Blood and Bone Marrow Pathology E-Book. Elsevier Health Sciences; 2011 May 27.

5. Coleman WB, Tsongalis GJ, editors. Essential concepts in molecular pathology. Academic Press; 2010 Feb 16.

6. Weatherall DJ, Clegg JB. The thalassaemia syndromes. John Wiley \& Sons; 2008 Apr 30.

7. Liu YT, Old JM, Miles K, Fisher CA, Weatherall DJ, Clegg JB. Rapid detection of alpha-thalassaemia deletions and alpha-globin gene triplication by multiplex polymerase chain reactions. British journal of haematology. 2000 Feb;108(2):295-9.

8. Roche (Cobas e411). Electrochemiluminescence immunoassay (ECLIA) for the in vitro quantitative determination of ferritin in human serum or plasma. http://www.roche diagnostics.ch/content/dam/corporate/rochedia_ch/documents/broschueren/professional_diagnostics/serumarbeitsplatz/immunologie/anamie/DE_Anı

9. Chong SS, Boehm CD, Higgs DR, Cutting GR. Single-tube multiplex-PCR screen for common deletional determinants of a-thalassemia. Blood. 2000 Jan 1;95(1):360-2

10. Applied Biosystem USA. Platinum ${ }^{\circledR}$ Multiplex PCR Master Mix. https://tools.thermofisher.com/content/sfs/manuals/4463722A.pdf. Retrieved in April 2011. 
11. Elderdery AY, Mohamed BA, Cooper AJ, Knight G, Mills J. Tribal distribution of haemoglobinopathies in a Sudanese patient population. Journal of Medical Laboratory and Diagnosis. 2011 Aug 31;2(4):31-7.

12. Higgs D. Molecular mechanisms of a thalassemia. Disorders of hemoglobin. 2001:405-30.

13. Modiano G, Morpurgo G, Terrenato L, Novelletto A, Di Rienzo A, Colombo B, Purpura M, Mariani M, Santachiara-Benerecetti S, Brega A, Dixit KA. Protection against malaria morbidity: near-fixation of the a-thalassemia gene in a Nepalese population. American journal of human genetics. $1991 \mathrm{Feb} ; 48(2): 390$.

14. DeLoughery TG. Microcytic anemia. New England Journal of Medicine. 2014 Oct 2;371(14):1324-31.

15. Higgs DR. The molecular basis of a-thalassemia. Cold Spring Harbor perspectives in medicine. 2013 Jan 1;3(1):a011718.

16. Matos JF, Borges KB, Fernandes AP, Faria JR, Carvalho MD. RDW as differential parameter between microcytic anemias in" pure" and concomitant forms. Jornal Brasileiro de Patologia e Medicina Laboratorial. 2015 Feb;51(1):22-7.

17. Pearson HA, Ehrenkranz RA, Rinder HM, Riely CA. Hemosiderosis in a normal child secondary to oral iron medication. Pediatrics. 2000 Feb 1;105(2):42930.

18. El-Kalla S, Baysal E. a-thalassemia in the United Arab Emirates. Acta Haematologica. 1998;100(1):49-53.

19. Mwakasungula S, Schindler T, Jongo S, Moreno E, Kamaka K, Mohammed M, Joseph S, Rashid R, Athuman T, Tumbo AM, Hamad A. Red blood cell indices and prevalence of hemoglobinopathies and glucose 6 phosphate dehydrogenase deficiencies in male Tanzanian residents of Dar es Salaam. International journal of molecular epidemiology and genetics. 2014;5(4):185.

20. Guimarães JS, Cominal JG, Silva-Pinto AC, Olbina G, Ginzburg YZ, Nandi V, Westerman M, Rivella S, de Souza AM. Altered erythropoiesis and iron metabolism in carriers of thalassemia. European journal of haematology. 2015 Jun;94(6):511-8.

21. Akhavan-Niaki H, Kamangari RY, Banihashemi A, Oskooei VK, Azizi M, Tamaddoni A, Sedaghat S, Vakili M, Nesheli HM, Shabani S. Hematologic features of alpha thalassemia carriers. International journal of molecular and cellular medicine. 2012;1(3):162.

22. Higgs DR, Vickers MA, Wilkie AO, Pretorius IM, Jarman AP, Weatherall DJ. A review of the molecular genetics of the human alpha-globin gene cluster. Blood. 1989 Apr 1;73(5):1081-104.

23. Borges E, Wenning MR, Kimura EM, Gervásio SA, Costa FF, Sonati MF. High prevalence of alpha-thalassemia among individuals with microcytosis and hypochromia without anemia. Brazilian Journal of Medical and Biological Research. 2001 Jun;34(6):759-62.

24. Sankar VH, Arya V, Tewari D, Gupta UR, Pradhan M, Agarwal S. Genotyping of alpha-thalassemia in microcytic hypochromic anemia patients from North India. Journal of applied genetics. 2006 Dec 1;47(4):391-5.

25. Rahim F. Microcytic hypochromic anemia patients with thalassemia: genotyping approach. Indian journal of medical sciences. 2009 Mar 1;63(3).

26. Bezerra CM, Meissner RV. Diagnóstico molecular da talassemia alfa+(deleção-a3. 7) em indivíduos com microcitose e/ou hipocromia atendidos no Hemocentro Dalton Barbosa Cunha em Natal, Rio Grande do Norte. Rev Bras Hematol Hemoter. 2010;32:90-1.

27. Wagner SC, Castro SM, Gonzalez TP, Santin AP, Filippon L, Zaleski CF, Azevedo LA, Amorin B, Callegari-Jacques SM, Hutz MH. Prevalence of common athalassemia determinants in south Brazil: Importance for the diagnosis of microcytic anemia. Genetics and molecular biology. 2010;33(4):641-5.

28. Azma RZ, Othman A, Azman N, Alauddin H, Ithnin A, Yusof N, Razak NF, Sardi NH, Hussin NH. Co-inheritance of compound heterozygous Hb Constant Spring and a single--a 3.7 gene deletion with heterozygous $\delta \beta$ thalassaemia: A diagnostic challenge. Malaysian Journal of Pathology. 2012 Jun 1;34(1).

29. Sharma M, Pandey S, Ranjan R, Seth T, Saxena R. Prevalence of alpha thalassemia in microcytic anemia: a tertiary care experience from North India. Mediterranean journal of hematology and infectious diseases. 2015;7(1).

30. Viprakasit V, Ayyub H, May A. Dinucleotide deletion in-a3. 7 allele causes a severe form of a+ thalassaemia. European journal of haematology. 2003 Aug;71(2):133-6.

31. Vayá A, Suescun M, Hernández JL, Pérez ML, Palanca S, Laiz B. Rheological red blood cell behaviour in minor a-thalassaemia carriers. Clinical hemorheology and microcirculation. 2011 Jan 1;48(4):241-6.

32. Ahmad R, Saleem M, Aloysious N, Yelumalai P, Mohamed N, Hassan S. Distribution of alpha thalassaemia gene variants in diverse ethnic populations in Malaysia: data from the Institute for Medical Research. International journal of molecular sciences. 2013 Sep;14(9):18599-614.

\section{Figures}




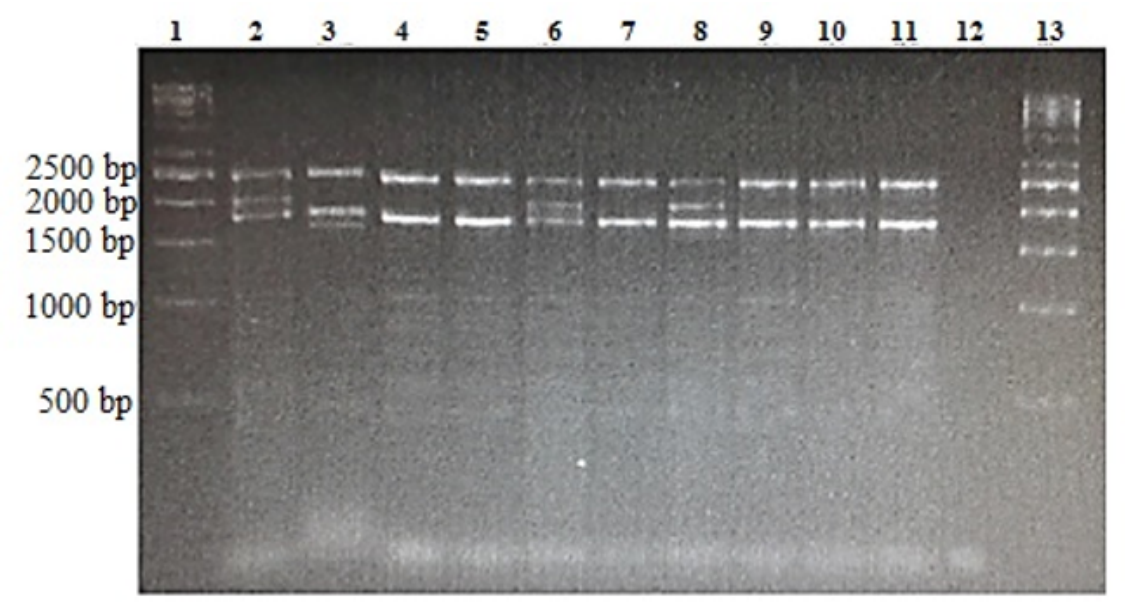

\section{Figure 1}

Multiplex PCR products on agarose gel electrophoresis. (a) Lane 1 and 13 were the DNA ladder ( $1 \mathrm{~Kb}$ ). (b) Lane 2 and 3 were the 3.7 and 4.2 heterozygous control samples respectively. (c) Lane 12 was the negative control. (d) Lane 4, 5, 7,9,10 and 11 were examples of negative sample result. (e) Lane 6 and 8 were example of heterozygous of 3.7deletion mutation. LIS1 primer was used as internal control for the amplification of the LIS1 as a house keeping gene and the product band size was of $2.5 \mathrm{~kb}$. The 3.7 and 4.2 deletions and the normal a2product bands size were $2.1,1.6$ and $1.8 \mathrm{~kb}$ repectivelly.

\section{Supplementary Files}

This is a list of supplementary files associated with this preprint. Click to download.

- STROBEchecklistcrosssectional.doc 